\title{
Thoughts on the evolution of modern oceans
}

\author{
I.S. Gramberg \\ All-Union Institute of Marine Geology and Mineral Exploration (VNII Okeangologia), \\ \#1 Maklina Av., 190121, St. Petersburg, Russia
}

Date Received April 15, 1993

Date Accepted January 20, 1994

\begin{abstract}
Explanation of the evolution of the Earth's oceans, particularly the processes involved in the generation of the oceans, are important for understanding the general appearance of our planet, and for the solution of specific problems. A comparative study of the world's oceans shows there is a single genetic series in the evolution of oceans, and that the oceans of the world are at different stages in their evolution. The Arctic Ocean, dated as Cenozoic, is noted for its small size and shallow oceanic floor, extensive but passive continental margins, limited volcanism, significant crustal thickness, and a lack of Benioff zones. The Mesozoic, Indian and Atlantic oceans have much greater dimensions and depths than the Arctic Ocean, the crust is thinner beneath them, volcanism is much more extensive, and active margins, while in the initial phase of evolution, are limited in extent. The area of the most ancient (probably Paleozoic) Pacific Ocean is equal to the sum of the rest of the three oceans; it also has the greatest oceanic depth. Beneath the Pacific, the crust is thinned and is characterized by high permeability, because of which magmatism is particularly widespread. Active continental margins are also extensive in the Pacific. The concept of evolutionary development of the oceans enables us to predict the comparative potential of oceans with regards to their oil and gas and ore content.
\end{abstract}

Les explications de l'évolution des océans de la terre, particulièrement les processus impliqués dans la formation des océans, sont importants pour comprendre l'aspect général de notre planète et pour la solution de problèmes spécifiques. Une étude comparative des océans du monde montre qu'il y a une suite génétique unique dans l'évolution des océans, et que les océans du monde en sont à différents stades dans leur évolution. L'océan Arctique, datant du cénozoïque, est caractérisé par sa petite taille et son fond océanique peu profond, des marges continentales étendues mais passives, une petite quantité de volcanisme, une croûte épaisse, et une absence de zones de Benioff. Les océans Indien et Atlantique, mésozoöques, ont des dimensions et des profondeurs beaucoup plus grandes que celles de l'océan Arctique, la croûte sous-jacente est plus mince; le volcanisme est beaucoup plus répandu, et les marges actives, dans leur phase initiale d'évolution, sont d'étendue limitée. La surface de l'océan Pacifique, le plus ancien (probablement paléozoïque), est égale à la somme des trois autres océans; il a aussi la plus grande profondeur. Sous le Pacifique, la croûte est amincie et caractérisée par une grande perméabilité, en raison de laquelle le magmatisme est particulièrement répandu. Les marges continentales actives sont aussi abondantes dans le Pacifique. Le concept de l'évolution des océans nous permet de prédire le potentiel comparatif des océans en regard de leur contenu en pétrole, gaz naturel et minerai.

[Traduit par la rédaction]

\section{INTRODUCTION}

A voluminous literature is available on the general geological structure of the world's oceans, but data on the distinctive structural features of specific oceans are generally incomplete. Nevertheless, important similarities and differences in the geological structure of the oceans are quite obvious. Moreover, it is quite clear that the specific characteristics of the world's oceans, including morphology, deep structure, the composition of sedimentary rock successions, and the intensity of volcanic activity differ quite distinctly from ocean to ocean.

Where did the differences originate? Answering this question is important because it is closely related to the question of the origin of the world's oceans (Bullard, 1969). The differences could reflect the different ways that the oceans might have originated; in other words, may be no single mechanism is capable of accounting for the formation of all oceans. However, the differences might also relate to the different ages of oceans and could reflect the different stages that each has reached in its evolution. If this is so, then all the oceans might indeed have followed a similar general pattern of evolution. A third possi- bility is that the differences are due to the specific geological environments that existed when the oceans originated and developed. That is to say, the distinctive geological structures of oceans would be determined by their position on the planet, by the pattern of the continental margins around them, by the varying intensity of subcrustal processes beneath them, and by other phenomena such as planetary impacts.

Understanding the mechanism and processes responsible for the origin and evolution of oceans is essential if we wish to explain the present day morphology of our planet and also to resolve specific practical problems such as the distribution of resources. Furthermore, recognition of the individual features of the oceans of the earth is of importance to the exploration for and estimation of their mineral resources. Today, in the early stages of study of the oceans, it is evident that they differ greatly from each other in their hydrocarbon and mineral potential. The emplacement of resources in the oceans is probably related directly to the specific structural features of each ocean basin. It is noteworthy, for example, that fields of $\mathrm{Fe}-\mathrm{Mg}$ nodules are widespread in the Pacific Ocean but are generally absent from the other oceans. At the same time, the high oil and gas poten- 
tial of the shelves and deep basins of the Arctic Ocean is also quite unique.

In addition to having distinctive differences, the oceans of the earth have much in common with each other. They are certainly structurally different from the continents. The oceans are characterized by a specific crustal structure (oceanic type), by the great areas of depths to the ocean floor, by the existence of mid-oceanic ridges and related rift zones, by dominantly basic volcanism, by the limited thickness and relatively young age of the sediment cover, and by specific assemblages of mineral resources such as Fe-Mg nodules, polymetallic sulfides, cobalt crusts, phosphorites and gas hydrates.

\section{Characteristics of OCEANS}

While study of the earth's oceans suggests that all oceans have some common structural features, individual oceans differ in size, morphology, crustal structure, geophysical properties, the scale and intensity of volcanic processes, in the thickness of sedimentary cover, sedimentation rates and mineral genesis. These characteristics are well-known and have been reported commonly in the literature (Shepard, 1948; Chase, 1975; Muratov, 1975; Bogolepov and Chikov, 1976; Strakhov, 1976; Pushcharovsky, 1980; Khain, 1984; Udintsev, 1989).

A comparison of geological data (see Tables 1 and 2) suggest that the world's oceans form a genetic or evolutionary series and that individual oceans are different because they are at different stages in their development. The Arctic Ocean is perhaps in the earliest phase of development because it is relatively small and relatively shallow (up to $5600 \mathrm{~m}$ ). Moreover, it has an extensive continental shelf that is comparable in area to the deep zones, and has large rises in its central part. The Arctic Ocean is underlain by subcontinental crust, and it has a thick sedimentary cover. Further, it is characterized by limited magmatic activity, mainly in the vicinity of the mid-oceanic ridge. The absence of Benioff zones is another distinctive feature of the Arctic Ocean.
Using the same parameters, the Indian and Atlantic oceans are probably intermediate in development between the younger Arctic Ocean and the older Pacific Ocean. The deep basins in the Indian and Atlantic oceans are 5.1 and 6.2 times respectively, larger than those in the Arctic Ocean. Similarly, the maximum depths of the Indian and Atlantic oceans are 2 to 3 times greater than the maximum depth of the Arctic Ocean. The continental shelf and margin of the Indian and Atlantic oceans, although fairly extensive, are still much smaller than the total area of those oceans. Furthermore, in the latter oceans, continental and subcontinental crust is limited in extent and magmatic activity has been recorded from within the mid-oceanic ridges as well as from extensive fault zones. The active continental margins in both oceans are in the early phase of development and are not particularly extensive. Finally, the sedimentary cover in the Indian and Atlantic oceans is of significant thickness only on the continental slopes and on adjacent parts of the sea floor (Emery and Uchupi, 1972; Levitan, 1984; Klitgord and Schouten, 1986; Levin, 1987; Gradstein et al., 1990).

By way of contrast, the area of the Pacific Ocean (Table 1) is comparable to the combined area of the three other oceans $(178684 \times 10 \mathrm{~m}$ for the Pacific and $182585 \times 10 \mathrm{~m}$ for the others). The maximum depth of the Pacific reaches $11 \mathrm{~km}$; its shelves are somewhat limited. The Pacific Ocean is underlain by typical oceanic crust, which is thinned and exhibits high permeability. Hence, magmatic activity is widespread and represented both by fissure- and central-type volcanoes. Finally, the sedimentary cover in the deep basins of the Pacific is relatively thin (Larson and Chase, 1972; Lancelot and Larson, 1975; Muratov, 1975; Batiza, 1982; Golovinsky, 1986; Levin, 1987).

It is now generally accepted that ocean basins have existed for a significant part of geological time and that the salinity of oceans was established early in their evolution. Subsequent changes in the world's oceans have been particularly dramatic and are related mainly to the evolution of organic life on earth and to the increase in the oxygen content of the atmosphere.

Table 1. A comparison of area and depth of the world's oceans and their marginal seas

\begin{tabular}{|c|c|c|c|c|c|}
\hline \multirow{2}{*}{$\begin{array}{l}\text { Area, depth of oceans } \\
\text { and marginal seas }\end{array}$} & \multirow{2}{*}{$\begin{array}{c}\text { Unit of } \\
\text { measurement }\end{array}$} & \multicolumn{4}{|c|}{ Ocean } \\
\hline & & Pacific & Indian & Atlantic & Arctic \\
\hline Total area of oceans & $1,000 \mathrm{~m}^{2}$ & 178,684 & 76,174 & 91,655 & 14,756 \\
\hline Total area of marginal sea & $1,000 \mathrm{~m}^{2}$ & 28,638 & 7,346 & 7,457 & 8,113 \\
\hline \multicolumn{6}{|l|}{ Area marginal seas } \\
\hline & $\%$ & 16.0 & 9.6 & 8.1 & 54.9 \\
\hline \multicolumn{6}{|l|}{ Area of Oceans } \\
\hline Average depth of ocean & m & 4,028 & 3,897 & 3,332 & 1,225 \\
\hline Maximum depth of ocean & $\mathbf{m}$ & 11,022 & 7,729 & 8,742 & 5,527 \\
\hline
\end{tabular}


Table 2. Comparison of major elements in the tectonic structure of the world's oceans

\begin{tabular}{lccccc}
\hline $\begin{array}{l}\text { Elements in tectonic } \\
\text { structure of oceans }\end{array}$ & $\begin{array}{c}\text { Unit of } \\
\text { measurement }\end{array}$ & Pacific & $\begin{array}{c}\text { Ocean } \\
\text { Indian }\end{array}$ & Atlantic & Arctic \\
\hline $\begin{array}{l}\text { Area of ocean plates } \\
\text { including arches and } \\
\text { blocky ridges }\end{array}$ & $1,000 \mathrm{~m}^{2}$ & 108,100 & 47,300 & 45,600 & 4,300 \\
$\begin{array}{l}\text { Area of oceanic mobile } \\
\text { belts (ridges) }\end{array}$ & $1,000 \mathrm{~m}^{2}$ & 35,100 & 15,900 & 20,000 & 200 \\
$\begin{array}{l}\text { Number of abyssal } \\
\text { trenches }\end{array}$ & unit & 11 & 1 & 4 & 0 \\
$\begin{array}{l}\text { Extent of Benioff zones } \\
\text { (after Lisitsin, 1980) }\end{array}$ & $\mathrm{km}$ & 24,000 & 3,900 & 2,120 & 0 \\
\hline
\end{tabular}

For a long time it was widely believed that once the oceans were formed they maintained their relative positions on the planet. It was thought that transgressions and regressions only changed the boundaries of the marginal seas. In some cases it was thought that the latter disappeared while the deep basins remained little touched. First, Wegener and later, many other specialists in global tectonics (Le Pichon et al., 1973; Karasik, 1974; Lisitsin, 1980; Pushcharovsky, 1980; Khain, 1984) critically reviewed the concept of oceanic stability. Now, there is little doubt that the oceans originated early in the Earth's history and that, through geological time, individual oceans opened and closed as a result of rifting, continental breakup, and sea-floor spreading. As new oceanic crust was generated, older crust descended into subduction zones.

These processes have been clearly confirmed through geological and geophysical observations in the modern oceans, but unfortunately such processes are less obvious for more ancient (Paleozoic and Precambrian) oceans. Indeed, the existence of the latter must be inferred from the distribution of ophiolites in ancient fold belts determined from paleomagnetic and paleographic reconstructions. Reconstruction of ancient closed oceans is a complex procedure and although numerous reconstructions have been presented in the literature most are in dispute to some degree. It seems clear that the modern oceans still hold many mysteries that must be investigated before the ancient oceans can be properly understood.

Most workers agree that the oceans of the world are of different ages and there is little serious dispute about the Cenozoic age for the Arctic Ocean and slightly older (Mesozoic) age for the Indian and Atlantic oceans (Karasik, 1974; Lisitsin, 1980; Pushcharovsky, 1980; Gradstein et al., 1990). Whereas the Pacific Ocean is considered to be the oldest ocean, its oldest sediments are of Middle Jurassic age, that is, the same age as the oldest sediments beneath the Atlantic. The reasons for this paradox remain unclear.

The age of sediments in the Pacific, Atlantic, and Indian oceans has been used to show that these oceans originated at approximately the same time (Lisitsin, 1980; Timofeev and Eremeev, 1987). These authors would agree that the Pacific, Indian and Atlantic oceans originated during the middle Mesozoic, and that the Arctic Ocean probably began somewhat later, that is, in the late Mesozoic or possibly as late as the Cenozoic. These Russian authors suggested that the world ocean system initially consisted of relatively shallow marine basins and that the modern oceans with their great depths evolved from that original ocean system.

However, if we accept the more-or-less contemporaneous origin of the Pacific, Indian and Atlantic oceans, how can we explain the highly significant differences in their geological character? These differences are reflected in ocean topography, in sedimentary structures, in the intensity and scope of volcanic activity, in continent-ocean junction patterns, and in the distribution of mineral resources. In fact; in all these parameters that characterize oceans, the Pacific Ocean is distinctly different from both the Indian and Atlantic oceans. These differences cannot be considered to be accidental and need to be accounted for. They certainly cannot be explained by assuming a common age of origin for the Pacific, Atlantic, and Indian oceans.

The continental margins of the Atlantic Ocean are considered to be passive and, therefore, the age of the oldest rocks in the sedimentary cover as well as the basaltic basement can be used to infer the time of origin of this ocean. The implication is that the Atlantic Ocean began to form in Middle Jurassic time.

On the other hand, the Pacific Ocean is characterized by active margins and exhibits continuous renewal of oceanic crust, comprising a basaltic basement and sedimentary cover. Therefore, it is apparent that the age of the basement and the oldest sediments resting on the basement cannot necessarily be used to date the time of origin of the ocean. In order to demonstrate the existence of an ancient Pacific Ocean it is important to search for parts of ancient oceanic crust on the sea floor of the modern Pacific Ocean; curiously, such crust has not yet been found. As in the Atlantic, the oldest sediments known from the Pacific Ocean are of Middle Jurassic age. It should be emphasized, how- 
ever, that even though the oldest sediments in the Pacific, Indian and Atlantic oceans are coeval, they differ greatly in sedimentary character, which probably reflects deposition in different paleoenvironments.

Some workers including Timofeev and Eremeev (1987), who studied the mineral composition and facies of Atlantic sediments, recognized lagoonal deposits, shallow terrigenous marine sediments, as well as shallow marine carbonates and evaporites that were deposited during early phases of the ocean's development in the Middle Jurassic-Early Cretaceous. The first deep marine sediments appeared during late Early Cretaceous, but the first pelagic sediments appeared during Late Cretaceous or Early Tertiary (Van Houten, 1977; Ogg et al., 1983; Gradstein et al., 1990).

A similar association is known from the Indian Ocean. According to Levitan (1984), thick terrigenous sequences were deposited in deltas, fore-deltas and submarine fans during the early stage of the ocean's development from the Late Jurassic to middle Cretaceous. This deposition may have been initiated by rapid subsidence and tectonic activity in contiguous parts of Gondwanaland (Levitan, 1984). Associated marine assemblages are represented by shallow water carbonates and evaporites. Pelagic clays, characteristic of deep oceanic zones, appear in the sedimentary succession of the Indian Ocean no earlier than the late Early Cretaceous or early Late Cretaceous.

Unlike the Atlantic and Indian oceans, deep water clay and siliceous clay sediments, typical of pelagic sedimentation, were recorded in the oldest part of the sedimentary succession in the Pacific Ocean. At Site 801, drilled during Leg 129 of JOIDES Resolution in the Marianas Trough, a $70 \mathrm{~m}$ thick succession of brown radiolarites rich in manganese oxide and dark-brown siliceous rocks was encountered. The radiolarite beds may be underlain by discontinuous, red, iron-rich radiolarite and mudstone beds of Middle Jurassic (Callovian) age. Fossils suggest that rocks lying at the base of the sequence were deposited during the Middle Jurassic, at the Callovian-Bathonian boundary.

The age and character of the oldest sediment in the Pacific, Indian and Atlantic oceans suggest that the oceanic regime existed since late Early Cretaceous time. Prior to that time, deltaic, lagoonal, and shallow water marine sequences were deposited in the Indian and Atlantic oceans. Unlike the Indian and Atlantic oceans, pelagic sediments are known from the lowest horizons of the sedimentary succession in the Pacific Ocean, as indicated earlier.

These findings are compatible with comparative sedimentation rates in the Pacific, Indian, and Atlantic oceans. The data listed in Table 3 suggest a fairly low weighted average sedimentation rate for the Pacific Ocean during the Late Jurassic-Early Cretaceous; such a rate is typical of abyssal basins. The weighted average sedimentation rates for comparable assemblages in the Indian and Atlantic oceans were 3 to 6 times higher than for the Pacific, and are more characteristic of shelf margins. During Late Cretaceous-Eocene time, the sedimentation rate decreased in all three oceans to a rate that is typical for pelagic sedimentation. The weighted average sedimentation rates in three oceans remained similar subsequent to the Oligocene-Pleistocene interval. It is important to note that during this latter period the world's oceans are characterized by an increase in depositional rate (Levin, 1987).
The above data support the continuity of oceanic sedimentation in the Pacific Ocean from Jurassic time onward, but they do not throw any new light on the ocean's pre-Jurassic history. That can be inferred only from indirect evidence provided by the structure and evolution of the continental margins of the Pacific Ocean (Krasny, 1974; Pushcharovsky and Melankholina, 1980; Golovinsky, 1986).

As mentioned above, the continental margins of the Pacific Ocean are, on the whole, "passive". They are separated from the ocean proper by abyssal trenches and, in the case of marginal seas, by island arcs and abyssal basins. Along the coast, extensively deformed sequences are conformable with the general configuration of the shoreline. These deformed sequences generally decrease in age inland suggesting a long existence for the active margins.

Although folding and mountain building in most of the mountain systems framing the Pacific shore took place in Mesozoic and Cenozoic time, the shelf troughs (earlier considered to be eugeosynclines) were emplaced as early as early Paleozoic time and persisted through the entire Paleozoic. Eardley (1962) arrived at the same conclusion through analysis of the geological history of North America as did Harrington (1962) on the basis of paleotectonic reconstructions of South America. Furthermore, the idea was confirmed by Krasny (1974) and Pushcharovsky and Melankholina (1980) during the course of reconstructing the geological history of far East and North East Russia. From the structure and geological history of coastlines we can conclude that the Pacific Ocean must have existed during Paleozoic time and that even then it was bordered by active margins.

With the exception of specific localized areas, the continental margins around the Atlantic and Indian oceans are passive. Certainly the continental margins of the world's youngest ocean, the Arctic Ocean, are passive. Considering data presented earlier in this report, it would appear that active margins were generated during specific stages of oceanic development, probably when the oceanic crust became mature and acquired unique rheological properties.

There is a direct relationship between the age (and hence degree of maturity) of the oceanic crust and the rate of sea-floor spreading (Table 3). The relatively young Arctic Ocean has the lowest spreading rate (Karasik, 1974) and the highest average spreading rates were recorded from the Pacific Ocean. According to the Le Pichon et al. (1973) spreading rates undoubtedly changed during the course of evolution of the world's oceans.

Despite differences in the geological structure of the world's oceans and the specific geological environments in which the oceans were formed, two main processes appear to have controlled their origin and development. These are sea floor spreading, that occurs during all stages of ocean development, and destruction of the continental crust, that mainly characterizes the early stage of ocean formation.

The unique structure of the Arctic Ocean illustrates the importance of the crustal destruction processes in ocean formation. The western Arctic Ocean (Eurasian Basin) exhibits all the features of a spreading ocean, while its eastern part (Amerasian Basin) has no spreading features at all. On the other hand, the Amerasian Basin provides insights into processes that are involved in destruction of the continental crust, part of which 
Table 3. Changes in the dynamics of geological processes during evolution of the world's oceans

Geological processes

(spreading and sedimentation)
Unit of

measurement
Ocean

Pacific Indian Atlantic Arctic
Calculated rate of sea floor spreading (mean values after

Le Pichon et al., 1973)

Calculated rate of sea floor spreading (variations after

Le Pichon et al., 1973)

Weighted average sedimentation rate for Jurassic-Lower Cretaceous assemblage after Levin (1987)

Weighted average sedimentation rate for Upper Cretaceous Eocene assemblage after Levin (1987)

Weighted average sedimentation rate for Oligocene-

Pleistocene assemblage after Levin (1987) $\mathrm{cm} /$ year

$\mathrm{cm} /$ year

$\mathrm{cm} / 10^{3}$ year

$\mathrm{cm} / 10^{3}$ year

$\mathrm{cm} / 10^{3}$ year

0.45

0.18

0.15
4.62

$1.1-9.9$

0.26

0.56

0.7
0.71

$0.3-1$

?

? is preserved within an array of extensive uplifts and isolated blocks.

The Amerasian Basin has attracted attention for many decades and a variety of models have been proposed to explain its peculiar structural character. First, in attempts to find evidence for spreading, the median position of the Mendeleev-Alpha ridge was invoked. However, recently collected data suggest that there may not have been any significant spreading, or indeed any spreading at all on the Medeleev-Alpha Ridge. In addition, the subcontinental character of the earth's crust in the vicinity of the Ridge has become better documented. Along with the Lomonosov Ridge in the central Arctic. Ocean, the Mendeleev-Alpha Ridge forms a system of intraoceanic structures that is underlain by continental crust, that is still in the early stages of destruction.

Subsequently, a widely-supported model suggested that the Amerasian Basin is part of the Pacific Ocean but is separated from the Pacific proper by an island arc system and microcontinents such as Meso-Cenozoic Alaska and Chukotka. This proposal is supported by paleomagnetic and paleogeographic evidence which points to the lateral displacement of Alaska and Chukotka during the Paleozoic and Mesozoic. Some suggestions have also been presented on the direction and rate of these displacement (Karasik et al., 1984). However, this model is not supported by geological data. The level of maturity of the earth's crust beneath the Amerasian Basin is in no way comparable to the crust under the Pacific Ocean. The Pacific crust is relatively thin, exhibits a linear magnetic field, has high permeability, intense volcanism, high seismicity, and active continental margins (Lancelot and Larson, 1975; Pushcharovsky and Melankholina, 1980; Batiza, 1982; Golovinsky, 1986). None of these characteristics have been reported from the Amerasian Basin.
The presence of marginal plateaus and subcontinental crustal blocks indicate that some destruction of the continental margins of the Amerasian Basin has occurred. Topographic highs (Mendeleev Ridge and Alpha Cordillera Ridge) occur in the deep part of the ocean. A particularly diagnostic feature is the fairly steep Amerasian slope of the Lomonosov Ridge; its step-like pattern is suggestive of a fault zone that has undergone erosion. All these arguments have led me to interpret the Amerasian Basin as an over-deepened ocean basin resulting from the destruction of the continental margin.

\section{OCEan Development}

The main geological features that influence the evolution of oceans gradually change during their evolution. During early stages in the development of the relatively young Arctic Ocean, structures that derived from rifting and the destruction of the continental crust are apparent. Similar processes led to development of both the Eurasian and Amerasian basins within the Arctic Ocean. During the next stage of ocean evolution, as exemplified by the Indian and Atlantic oceans, rifting and spreading through the mid-oceanic rift zones dominated ocean development. Destruction of continental crust beneath the coasts was still ongoing in those oceans but at a much reduced rate. Areas underlain by oceanic crust characterized by high permeability are marked by fissure- and central-volcanoes. The latter are responsible for a more complex bottom topography and for the emplacement of volcanic ridges and island chains over "hot spots". Active margins begin to form at this stage of ocean development.

In even more mature oceans, such as the Pacific Ocean, the processes of ocean evolution are controlled mainly by rifting and spreading related to the mid-oceanic ridges and by local 
spreading. The rejuvenation of oceanic crust by fissure- and central-volcanoes is a process that continually expands in extent. Not only this expansion but also the efficiency of the process might be attributed to the high permeability of the mature oceanic crust. In consequence, the sea floor of the Pacific Ocean is complicated by numerous central-type volcanic edifices, by volcanic ridges related to fractures, by chains of submarine volcanoes and islands which owe their origin to hot spots. The active continental margins, where destruction of margins and subduction take place, are the main sites for continental collision.

Thus, during the early stage of ocean formation (Arctic Ocean), rifting (spreading) and the destruction of continental crust are processes of equal importance. Later, during the transition to somewhat more developed basins (Atlantic and Indian oceans), and finally to a mature ocean (Pacific), the process of destruction of the continental crust in the coastal regions and the separation of large crustal blocks became increasingly important. The brittleness and permeability of the oceanic crust appears to have increased with maturity. The rate of rejuvenation of the crust increased because of rifting and the activity of central volcanoes. Not only high spreading rates but also the relatively young age of both the basaltic basement and overlying sediments suggest a rapid rate of rejuvenation of oceanic crust beneath the Pacific. In this context, a comparison of sediments of different ages in the three oceans where deep-sea drilling has been conducted is of great interest (Levin, 1987). The fact that Middle Jurassic deposits represent the oldest sedimentary units in all three of these oceans (Pacific, Indian and Atlantic) permits the inference that the crust beneath them might also be of Middle Jurassic age. As a result of subsequent rejuvenation of the sea floor 180 million years ago, the youngest (Oligocene-Pleistocene) deposits overlying the basement rocks amount to $35 \%, 23 \%$ and $22 \%$ of the area of the Pacific, Indian, and Atlantic oceans respectively (Table 4).

Data in Table 4 suggest that rejuvenation of crust occurs most quickly in the Pacific Ocean, despite its vast area. This is undoubtedly determined by a number of factors, of which the most important might be the thin and highly permeable nature of the mature oceanic crust. Extensive Benioff zones coincide with areas of crustal rejuvenation near sites of scattered spreading and intraplate magmatism.

\section{RESOURCE POTENTIAL OF THE WORLD'S OCEANS}

The slow, stage-by-stage evolution of the earth makes it possible to predict the oil and gas potential and mineralization of the world's oceans. For example, the high sedimentation rate, great thickness of sedimentary cover, extensive continental margins, and large continental crustal blocks in the central part of the Arctic Ocean suggest that this ocean might be a huge oil-and gas-bearing superbasin (Gramberg et al., 1983). At the same time, magmatic activity is related mainly to the mid-oceanic ridge and because of this and the low permeability of the crust, hydrothermal activity is somewhat confined. Therefore, in terms of mineral resources such as iron and magnesium nodules and cobalt crust, the mineral potential of the Arctic Ocean is rela- tively low. The Indian and Atlantic oceans are underlain mainly by oceanic crust and accordingly, the oil and gas potential is confined to the continental shelves and slopes and adjacent sedimentary basins. Deep basins, whose sedimentary cover is thin, with low organic content and few good reservoirs must be considered to have relatively poor oil and gas potential.

The volcanic and hydrothermal activity of the Indian and Atlantic oceans is more intensive than that of the Arctic Ocean and therefore the former have a higher potential for oceanic ore deposits. The inference is supported by the discovery of fields of iron and magnesium nodules in the Indian and Atlantic oceans and massive sulfide ores in the Atlantic Ocean. However, one should take into account that the permeability of oceanic crust in the Indian and Atlantic oceans is lower than in the Pacific Ocean; hence, the supply of hydrothermal ore material in the Indian and Atlantic ocean waters is somewhat limited. This suggests that the potential for generation of nodules rich in nickel, copper, and cobalt is somewhat more limited in the Indian and Atlantic oceans than in the Pacific Ocean.

These inferences cannot be directly applied to estimate the potential for polymetallic sulfide ores in the Indian and Atlantic oceans; the generation of these ores is determined by other factors, such as the composition of the oceanic crust, the intensity of thermal fluid migration, and the leaching of ore components.

Unlike the Pacific Ocean, the accumulation of massive sulfide ores in the Indian and Atlantic oceans appears to be restricted to the mid-oceanic ridges and transform faults where the hydrothermal processes are most active. However, ore deposits might also be buried under the sedimentary cover in these oceans considering that the sedimentation rate is much higher than in the Pacific.

The entire sea floor of the Pacific Ocean is underlain by mature oceanic crust. Isolated crustal blocks composed of subcontinental and continental crust amount to a small fraction of the entire ocean area. Hence, the oil and gas potential of the Pacific Ocean is more or less confined to the shelf zones and continental margins. These are of limited extent compared to the ocean proper. On the other hand, the high permeability of the earth's crust beneath the Pacific Ocean controls the supply of volcanic material and other products of thermal activity deposited on the sea floor. The widespread distribution of ore constituents and the diversity of iron-magnesium nodule types in the Pacific Ocean may well be attributed to this phenomenon (Bichoff and Roschbauer, 1977).

In the Pacific Ocean there is a pronounced vertical geochemical zonation that characterises accumulations of nickel, copper and cobalt in Fe-Mg nodules. Polymetallic sulfide ores have been reported from different structural zones in the $\mathrm{Pa}$ cific Ocean. Substantial accumulations of ores with high zinc and copper content, and in some cases accessory silver, occur on the active spreading ridges. In recent years, the occurrence of sulfide ores has been reported from back-arc zones. It is noteworthy that they also exhibit a high gold content. Because of the many variables introduced by the high permeability of the earth's crust, the intensity of tectonic processes, and the extent of volcanic and hydrothermal activity, it is clear that marine 
Table 4. The distribution of deep basin sediments during evolution of the world's oceans (inferred from deep-sea drilling data)

Distribution of sediments overlying the basalt basement (in \% of the ocean area)

\begin{tabular}{lccc} 
Ocean & $\begin{array}{c}\text { Late Jurassic-Early } \\
\text { Cretaceous time }\end{array}$ & $\begin{array}{c}\text { Late Cretaceous- } \\
\text { Eocene time }\end{array}$ & $\begin{array}{c}\text { Oligocene- } \\
\text { Pleistocene }\end{array}$ \\
\hline Pacific & 15.9 & 18.9 & 35.1 \\
Indian & 14.8 & 35.5 & 22.7 \\
Atlantic & 12.3 & 26.4 & 22.4 \\
\hline
\end{tabular}

geologists are still in the initial stages of understanding the metallogenesis of the Pacific Ocean. This is one of many challenges facing tomorrow's oceanographers.

The author hopes that this review will cause some of his colleagues to challenge existing interpretations and forward our understanding of the world's oceans.

BatizA, R.V. 1982. Abundance, distribution and sizes of volcanoes in the Pacific Ocean and implication for the origin of non-hot-spot volcanoes. Earth and Planetary Science Letters, 80, pp. 196-206.

Bischoff, I.L. and Roschbauer, R.I. 1977. Recent metalliferous sediment in the North Pacific manganese nodule area. Earth and Planetary Science Letters, 33, pp. 379-388.

Bogolepov, K.V. and ChiKov, B.M. 1976. Geology of the first ocean. Izd. Nauka, Moscow, 248 p. (in Russian).

Bullard, E.C. 1969. The origin of the oceans. Scientific American, 221, pp. 66-75.

Chase, T.E. 1975. Topography of the oceans. Map scale 1:47520 000. Scripps Institute of Oceanography, San Diego.

Eardley, A.Y. 1962. Structural Geology of North America. Second edition. Harper and Row, New York, 743 p.

EMERY, K.O. and UchupI, E. 1972: Western North Atlantic Ocean: Topography, rocks, structure, water, life and sediments. American Association of Petroleum Geologists, Memoir 17, 532 p.

Golovinsky, V.I. 1986. Tectonics of the Pacific Ocean. Moskva Nedra, 197 p. (in Russian).

Gradstein, F.M., Jansa, L.F., Srrivastava, S.P., Williamson, M.A., Bonham-Carter, G., and Stam, B. 1990. Aspects of North Atlantic paleo-oceanography, Chapter 8. In Geology of the Continental Margin of Eastern Canada. Edited by M.J. Keen and G.L. Williams. Geological Survey of Canada, Geology of Canada, 2, pp. 351-389.

Gramberg, I.S., Kraev, A.G., and Karasik, A.M. 1975. Geotectonic premises for the oil-and gas potential of the northern seas of the USSR. Sovetskaya Geologia, 2, pp. 17-24.

Gramberg, I.S., Kulakov, Yu.N., Pogrebitsky, Yu.E., and Sorokov, D.S. 1983. Arctic Oil and Gas Superbasin, Exploration in New Regions. Eleventh World Petroleum Congress, London, 11, pp. 93-99.

Harrington, H.J. 1962. Paleogeographic development of South America. Bulletin of the American Association of Petroleum Geologists, 46, pp. 1773-1814.
KARASIK, A.M. 1974. The Eurasian Basin of the northern Arctic Ocean in respect to plate tectonics. Geologiya Arckt., Leningrad Nauchno Issled Institut. In Problemy geologii Polyarnykh Oblastey Zemli. Sbornik Statey, pp. 23-31.

Karasik, A.M., Ustritsky, V.I., and Khramov, A.N. 1984. History of the formation of the Arctic Ocean by Gramberg, I.S., Karasic, A.M., Krasilshchikov, A.A., Pogrebitsky, Yu.E., Sorokov, D.S., and Yeshim, D.S. Colloquium 4, International Geological Congress, 27, pp. 178-189.

KhaIN, V.E. 1984. Tectonics of the lithospheric plates: results and unresolved problems. Akademiya Nauk, SSSR, Izvestiya, Seriya, Geologicheskaya, 12, pp. 23-37 (in Russian).

KLITGORD, K.D. and Schouten, H. 1986. Plate kinematics of the Central Atlantic. In The Geology of North America, v. M, The Western North Atlantic region. Edited by P.R. Vogt and B.E. Tucholke. Geological Society of America, Boulder, Colorado, pp. 351-378.

KRASNY, L.I. 1974. The system of blocks generated by crustal disintegration in eastern Asia and the western Pacific. Doklady Akademiya Nauk, SSSR, 214, pp. 414-417 (in Russian).

Lancelot, Y. and LaRson, R.L. 1975. Sedimentary and tectonic evolution of the North-western Pacific, Deep Sea Drilling Project, leg. 32. In Initial Reports of the Deep Sea Drilling Project. United States Government Printing Office, Washington, D.C., 32, pp. 925-939.

Larson, R.L. and Chase, K.G. 1972. Late Mesozoic evolution of the Western Pacific ocean. Bulletin of the Geological Society of America, 83, pp. 3624-3644.

Le Pichon, X., Francheteau, J., and Bonnin, J. 1973. Plate Tectonics. Elsevier, Amsterdam, 302 p.

LEvin, L.E. 1987. Global and regional regular features in the structure of a sedimentary cover of seas and oceans. In Litologia mezozoisko-kainozoiskogo osaadochnogo chekhla Mirovogo okeana. Moskva Nauka, pp. 28-36 (in Russian).

Levitan, M.A. 1984. Paleooceanology of the Indian Ocean. International Geological Congress 27, Colloquium 3M. Moskva, Doklady, Nauka, pp. $61-72$ (in Russian).

Lisitsin, A.P. 1980. Geology of the ocean; geological history of the ocean. Oceanology, 2, Izvestiya Moskva Nauka in Geologicheskkaya, 464 p.

Muratov, M.V. 1975. Origin of the continents and oceans basins. Moskva Nauka, 176 p. (in Russian).

OgG, J.G., Robertson, A.H.F., and JANSA, L.F. 1983. Jurassic sedimentation history of Site 534 (western North Atlantic-Tethys Sea- 
way). In Initial Reports of the Deep Sea Drilling Project, Volume 7b. Edited by R.S. Sheridon and F.M. Gradstein. United States Government Printing Office, Washington, D.C., pp. 829-884.

Pushcharovsky, Yu.M. 1980. Problems relevant to ocean tectonics. In Tectonika $\mathbf{v}$ issledovaniyakh Geologicheskogo Instituta AN SSSR. Moskva Doklady, Nauka, pp. 123-175 (in Russian).

Pushcharovsky, Yu.M. and Melankholina, E.N. 1980. Tectonics of the northwestern Pacific Ocean. Geotectonika, 2, pp. 3-12 (in Russian).

ShePard, F.P. 1948. Submarine geology. Second edition, 1963. Harper and Row, New York, 557 p.

Strakhov, N.M. 1976. Problems of geochemistry in recent ocean lithogenesis. Moskva, Nauka, 298 p. (in Russian)
Timofeev, P.P. and Eremeev, V.V. 1987. Mesozoic and Cenozoic history of the sedimentary cover of the Atlantic Ocean. In Litologia mezozoisko-kainozoiskogo osadochnogo chekhla Mirovogo okeana. Edited by P.P. Timofeev and V.N. Kholodov. Akademiya Nauk SSSR, Mezhduvedomstvennyy Komitet SSSR, pp. 12.28 (in Russian).

Udintsev, G.V. 1989. Topography and structure of oceans. Moskva Nedra, 237 p. (in Russian).

Van Houten, F.B. 1977. Triassic-Liassic deposits, Morocco and eastern North America: a comparison. Bulletin of the American Association of Petroleum Geologists, 61, pp. 79-99. 